\title{
An Improved Synthesis of 4'-Hydroxydiclofenac
}

\author{
Sang-Hyun Kim, Jung-Hwan Kwon, ${ }^{\dagger}$ and Sung-Hwa Yoon ${ }^{*}$ \\ Department of Molecular Science and Technology Ajou University, Suwon 443-749, Korea. *E-mail: shyoon@ajou.ac.kr \\ ${ }^{\dagger}$ Department of Environmental Engineering, Ajou University, Suwon 443-749, Korea \\ Received August 1, 2010, Accepted August 18, 2010
}

Key Words: Diclofenac, Metabolites, 4'-Hydroxydiclofenac, Improved synthesis

Diclofenac (DCF, 1 ) has been widely used as a non-steroidal anti-inflammatory drug (NSAID) for its antipyretic, anti-inflammatory and analgesic properties and is metabolized to 4'hydroxydiclofenac (4'-OH DCF, 2) and 5-hydroxydiclofenac (5-OH DCF) by cytochrome P450 (CYP) enzymes such as CYP 2C9 and CYP 3A4. ${ }^{1-3}$ Although 1 is an effective and safe product, recent reports showed that one or more hydroxylated metabolites of $\mathbf{1}$ are related to the adverse effects of $\mathbf{1}$, which were exemplified by hepatotoxicity. ${ }^{4}$ Numerous reports related to the diclofenac metabolism and its toxicological consequences have indicated that metabolites of 1 possess a different activity from 1, resulting in various side effects or toxicities, and that hepatotoxicity is mainly induced by metabolites of $\mathbf{1}$ rather than by 1 itself. $^{5-6}$ In addition, the environmental effects of these hydroxyl metabolites to non-target organisms have recently

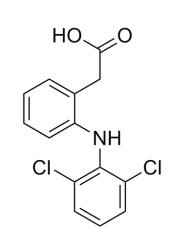

Diclofenac 1

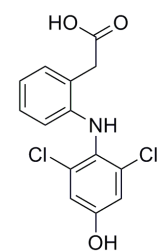

4'-Hydroxydiclofenac 2
Figure 1. Structures of diclofenac (1) and 4'-hydroxydiclofenac (2). become of great concern due to their toxicities. ${ }^{7}$ In connection with our ongoing project investigating the environmental fate and ecotoxicological effects of $\mathbf{1}$ and its metabolites on the environment, we need to synthesize substantial quantities of $\mathbf{2}$.

The synthesis of $\mathbf{2}$ has been well described in two previous studies by Waterhouse et $a l^{8}{ }^{8}$ and Kenny et al. ${ }^{9}$ but these synthetic methods were not entirely satisfactory for scale-up reaction due to low overall yield and harsh reaction conditions. Waterhouse and colleagues synthesized 2 from 3,5-dichlorophenol using $N$-(2,6-dichloro-4-methoxyphenyl)acetamide as the key intermediate, but the yield in the cyclization step of the key intermediate was only $12 \%$, which resulted in a very low overall yield (3.63\%). The other method for the synthesis of 2 by Kenny's group afforded a better overall yield (16.1\%). However, the method remains inappropriate for scale-up due to its low yield and harsh conditions, especially the chlorination step (step b) at $-15{ }^{\circ} \mathrm{C}$, coupling reaction (step c) using activated copper, and hydrolysis (step e). (Scheme 1) Therefore, we modified Kerry's method by changing the key intermediate as well as the reaction conditions, and here describe the a new synthetic method for $\mathbf{2}$ which is safer and has a much better yield $(58.2 \%)$ than the reported method.

As depicted in Scheme 1, we first synthesized benzoquinone monoxime 4 from phenol 3 in $85 \%$ yield by following the previously reported method, in which 2,6-dichloro-4-methoxy-

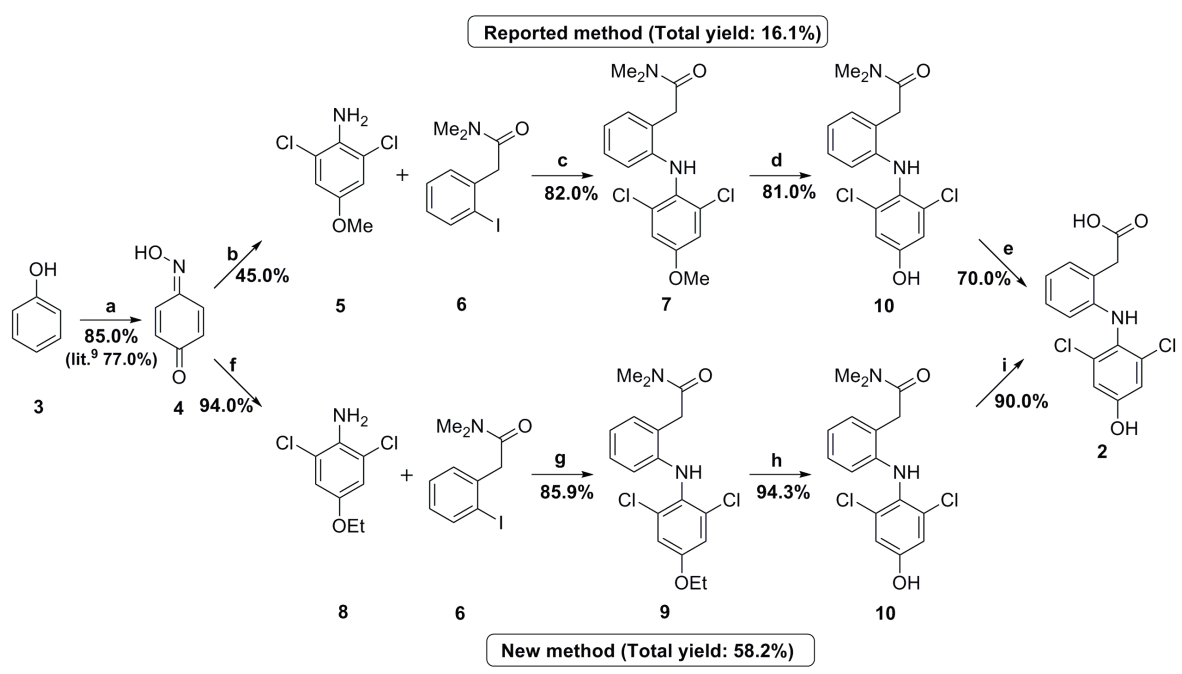

Scheme 1. Reagents: (a) $\mathrm{H}_{2} \mathrm{SO}_{4}, \mathrm{NaNO}_{2}, \mathrm{H}_{2} \mathrm{O}$, below $0{ }^{\circ} \mathrm{C}$; (b) saturated $\mathrm{HCl}$ in methanol, methanol/Et $2 \mathrm{O}(\mathrm{v} / \mathrm{v}=1 / 3),-15{ }^{\circ} \mathrm{C}, 1 \mathrm{~h}$; (c) activated copper, $\mathrm{CuI}, \mathrm{K}_{2} \mathrm{CO}_{3}$, DMF, $150{ }^{\circ} \mathrm{C}, 20 \mathrm{~h}, \mathrm{~N}_{2}$; (d) $1.0 \mathrm{MBBr}_{3}$ in $\mathrm{CH}_{2} \mathrm{Cl}_{2}, \mathrm{rt}, 1 \mathrm{~h}$; (e) $1.0 \mathrm{~N} \mathrm{NaOH}$ solution, ethanol, $80^{\circ} \mathrm{C}, 24 \mathrm{~h}, \mathrm{~N}_{2}$; (f) $4.0 \mathrm{~N} \mathrm{HCl}$ in 1,4-dioxane, ethanol, rt, $1 \mathrm{~h}$; (g) KI, CuI, $\mathrm{K}_{2} \mathrm{CO}_{3}$, DMF, $150{ }^{\circ} \mathrm{C}, 20 \mathrm{~h}, \mathrm{~N}_{2}$; (h) $1.0 \mathrm{M} \mathrm{BBr}_{3}$ in $\mathrm{CH}_{2} \mathrm{Cl}_{2}, \mathrm{rt}, 1 \mathrm{~h}$; and (i) $1.0 \mathrm{~N}$ $\mathrm{NaOH}$ solution, ethanol, $\mathrm{CuCl}, 90^{\circ} \mathrm{C}, 24 \mathrm{~h}, \mathrm{~N}_{2}$ 
aniline $\mathbf{5}$ was used as a key intermediate for the synthesis of $\mathbf{2}^{10}$ For the synthesis of $\mathbf{5}$, the Kenny group converted $\mathbf{4}$ into $\mathbf{5}$ by dropwise addition of a solution of $\mathbf{4}$ into methanol while $\mathrm{HCl}$ gas was continuously added while keeping a constant surface temperature between $-10{ }^{\circ} \mathrm{C}$ and $0{ }^{\circ} \mathrm{C}$. However, these methods resulted in a poor yield of less than $45 \%$ due to the formation of 2,4-dimethoxy-6-chloroaniline as a byproduct. In addition, when we raised the reaction temperature to room temperature, we obtained 2,4-dimethoxy-6-chloroaniline as a major product. Since it is difficult to control the low-temperature reaction during the saturation of $\mathrm{HCl}$ gas in the dichlorination of 4 , we needed to find a new intermediate that is stable at room temperature. To improve the yield and reaction condition in the dichlorination step (step b), we investigated different chlorination reaction conditions and temperatures, and found that, instead of the addition of methanol at $-15^{\circ} \mathrm{C}$, the dropwise addition of an ethanol solution of 4 into $4.0 \mathrm{~N} \mathrm{HCl}$ in 1,4-dioxane with continuous passage of $\mathrm{HCl}$ gas at room temperature afforded 2,6-dichloro-4-ethoxyaniline $\mathbf{8}$ in significantly better yield (94\%) than the reported yield (45\%). The same dichlorination reaction with propanol did not produce any corresponding propoxy compound.

For Ullmann coupling reaction of $\mathbf{5}$ with $N, N$-dimethylamide $\mathbf{6},{ }^{11}$ the previous methods used activated copper as a catalyst (step c). Despite the high yield of this reaction with activated copper, the preparation process of activated copper is very dangerous because of the use of the hydrogen-nitrogen mixture gas. To avoid this harsh condition, we used potassium iodide, which is a safe and cheap reagent, as a catalyst instead of activated copper. In this new reaction condition, the nucleophilic aromatic 8 was easily coupled with the aryl halide $\mathbf{6}$ at elevated temperature $\left(150{ }^{\circ} \mathrm{C}\right)$ to give 9 in $85.9 \%$ yield. This rendered the performance of the above Ullmann reaction under this condition easy, simple and safe. Deethylation (step h) of 9 with $\mathrm{BBr}_{3}$ also produced 10 in better yield (94.3\%) than the reported yield $(81.0 \%)$ in the demethylation of 7.

The final hydrolysis step (step e) in the reported method required an inert condition by Schlenk tube to avoid the generation of the free radicals that induce cyclization of $\mathbf{1 0}$. In the presence of oxygen during the reaction, the free radical generated on the amine attacked the carbonyl group to produce the indoline-2-one cyclic byproduct. To prevent the formation of this cyclized byproduct, we added $\mathrm{CuCl}$ to scavenge the free radical since $\mathrm{Cu}$ (I) is easily converted to $\mathrm{Cu}$ (II) by catching the free radical. ${ }^{12-13}$ As a result, when the hydrolysis reaction was performed in the presence of a catalytic amount of $\mathrm{CuCl}$, a significant decrease of cyclic byproduct formation was observed by electrospray ionization-mass spectrometry (ESI-MS), which eventually increased the yield of that step from $70.0 \%$ to $90.0 \%$.

In conclusion, we synthesized 4'-hydroxydiclofenac with an overall yield 3.6 times better than that of the reported method by changing the intermediate and the reaction conditions. The new synthetic method can be applied for the syntheses of other diclofenac derivatives with safer reaction conditions.

\section{Experimental Section}

Instruments. Melting points were determined on a Fisher-
Johns melting point apparatus and are uncorrected. Infrared spectra were recorded on a Nicolet 6700 FT-IR spectrometer. ${ }^{1} \mathrm{H}$ NMR and ${ }^{13} \mathrm{C}$ NMR spectra were recorded on a Varian Gemini 400 spectrometer at $400 \mathrm{MHz}$ and $100 \mathrm{MHz}$, respectively. The chemical shifts given are relative to tetramethylsilane. Mass spectra were measured on a Shimadzu LCMS-2010EV (Chiyoda-Ku, Tokyo, Japan) mass spectrometer. Column chromatography was carried out using Merck silica gel 60 (230 - 400 mesh).

Benzoquinone monoxime (4). Concentrated $\mathrm{H}_{2} \mathrm{SO}_{4}(6.25 \mathrm{~g}$, $63.7 \mathrm{mmol}$ ) was added dropwise to a solution of phenol 3 $(5.00 \mathrm{~g}, 53.1 \mathrm{mmol})$ and $\mathrm{NaNO}_{2}(4.40 \mathrm{~g}, 63.7 \mathrm{mmol})$ in water $(120 \mathrm{~mL})$ at $0{ }^{\circ} \mathrm{C}$. After $1 \mathrm{~h}$, the solid formed was filtered off and washed with cold water to obtain the product 4 (4.50 g). The mother liquid was extracted with EtOAc $(200 \mathrm{~mL})$. The organic layer was dried over $\mathrm{Na}_{2} \mathrm{SO}_{4}$ and concentrated in vacuo to give the residue, which was purified by chromatography with EtOAc as an eluent to afford further product as a brown solid (1.06 g). Total yield was $85.0 \%$ (5.56 g); mp $139-141{ }^{\circ} \mathrm{C}$; IR $\left(\mathrm{KBr}, \mathrm{cm}^{-1}\right) 3483,1630 ;{ }^{1} \mathrm{H}$ NMR (DMSO- $\left.d_{6}\right) \delta$ 6.298-6.322 $(\mathrm{d}, 2 \mathrm{H}, J=9.6 \mathrm{~Hz}), 6.848$ (s, 1H), 7.162-7.185 (d, 1H, $J=9.2$ $\mathrm{Hz}), 7.633-7.655$ (d, $1 \mathrm{H}, J=8.8 \mathrm{~Hz}) ;{ }^{13} \mathrm{C} \mathrm{NMR}$ (DMSO- $\left.d_{6}\right) \delta$ 124.258, 129.168, 131.061, 138.304; ESI-MS: M-H' $(\mathrm{m} / \mathrm{z}) 122$.

2,6-Dichloro-4-ethoxyaniline (8). Dry $\mathrm{HCl}$ gas was passed into $4 \mathrm{~N} \mathrm{HCl}$ in 1,4-dioxane $(120 \mathrm{~mL})$ under a nitrogen atmosphere, which was stirred at room temperature until saturation had been achieved. A solution of 4 (5.00 g, $40.6 \mathrm{mmol})$ in EtOH $(50 \mathrm{~mL})$ was added dropwise with continued $\mathrm{HCl}$ passage into the 1,4-dioxane solution. The $\mathrm{HCl}$ passage was continued for $1 \mathrm{~h}$ after addition was completed. The solvent was partially evaporated and the remaining mixture (about $50 \mathrm{~mL}$ ) was basified to $\mathrm{pH} 7$ using $1 \mathrm{~N} \mathrm{NaOH}(60 \mathrm{~mL})$. The neutralized mixture was extracted with EtOAc $(250 \mathrm{~mL})$, and the organic layer was concentrated to give residue, which was chromatographed, by eluting with EtOAc/hexane (v/v, 1/9) to afford 8 as a pale brown semisolid (7.86 g, 94.0\%); $\mathrm{mp} 41-42{ }^{\circ} \mathrm{C}$; IR $\left(\mathrm{KBr}, \mathrm{cm}^{-1}\right) 3327$, 3287; ${ }^{1} \mathrm{H}$ NMR $\left(\mathrm{CDCl}_{3}\right) \delta$ 1.342-1.377 (t, 3H, $\left.J=7.2 \mathrm{~Hz}\right)$, 3.886-3.938 (q, 2H, $J=7.2$ and $6.8 \mathrm{~Hz}), 4.074(\mathrm{~s}, 2 \mathrm{H}), 6.789$ $(\mathrm{s}, 2 \mathrm{H}) ;{ }^{13} \mathrm{C} \mathrm{NMR}\left(\mathrm{CDCl}_{3}\right) \delta 15.019,64.724,115.074,120.292$, 134.186, 150.802; ESI-MS: $\mathrm{M}+\mathrm{H}^{+}(\mathrm{m} / \mathrm{z}) 206$.

2-(2-(2,6-Dichloro-4-ethoxyphenylamino)phenyl)- $N, N$-dimethylacetamide (9). A mixture of 2-(2-Iodophenyl)- $N, N$ dimethylacetamide (2.00 g, $6.92 \mathrm{mmol}), 8(2.14 \mathrm{~g}, 10.4 \mathrm{mmol})$, potassium iodide (1.15 g, $10.4 \mathrm{mmol})$, copper iodide (1.32 g, $6.92 \mathrm{mmol})$, and potassium carbonate $(1.91 \mathrm{~g}, 13.8 \mathrm{mmol})$ was stirred and heated at reflux in DMF $(15 \mathrm{~mL})$ for $20 \mathrm{~h}$ under a nitrogen atmosphere. After the mixture was cooled down, it was filtered through celite. The filtrate was concentrated, and then re-dissolved in EtOAc $(100 \mathrm{~mL})$. The organic layer was washed with water $(70 \mathrm{~mL})$ and concentrated to give solid residue, which was purified by chromatography with EtOAc/hexane (v/v, 2/3) to afford 9 as a brown solid (2.18 g, 85.9\%); mp 136 $137{ }^{\circ} \mathrm{C}$; IR $\left(\mathrm{KBr}, \mathrm{cm}^{-1}\right) 3208,1621 ;{ }^{1} \mathrm{H}$ NMR $\left(\mathrm{CDCl}_{3}\right) \delta 1.395-$ $1.429(\mathrm{t}, 3 \mathrm{H}, J=6.8 \mathrm{~Hz}), 2.975(\mathrm{~s}, 3 \mathrm{H}), 3.184(\mathrm{~s}, 3 \mathrm{H}), 3.826(\mathrm{~s}$, $2 \mathrm{H}), 3.969-4.022(\mathrm{q}, 2 \mathrm{H}, J=7.2$ and $6.8 \mathrm{~Hz}), 6.342-6.316(\mathrm{~d}$, $1 \mathrm{H}, J=7.6 \mathrm{~Hz}), 6.779-6.818(\mathrm{~m}, 1 \mathrm{H}), 6.914$ (s, 2H), 7.019$7.061(\mathrm{~m}, 1 \mathrm{H}), 7.102-7.124(\mathrm{dd}, 1 \mathrm{H}, J=8.0$ and $1.6 \mathrm{~Hz}), 7.459$ $(\mathrm{s}, 1 \mathrm{H}) ;{ }^{13} \mathrm{C} \mathrm{NMR}\left(\mathrm{CDCl}_{3}\right) \delta 14.826,36.062,38.117,38.223$, 
64.251, 114.996, 115.390, 119.645, 122.709, 127.547, 130.316, 130.429, 132.348, 144.672, 155.426, 171.292; ESI-MS: $\mathrm{M}+\mathrm{H}^{+}$ $(\mathrm{m} / \mathrm{z}) 367$.

2-(2-(2,6-Dichloro-4-hydroxyphenylamino)phenyl)- $\mathrm{N}, \mathrm{N}$ dimethylacetamide (10). A $1 \mathrm{M}$ solution of $\mathrm{BBr}_{3}$ in dichloromethane $(50 \mathrm{~mL})$ was added dropwise to a solution of $9(2.10 \mathrm{~g}$, $5.72 \mathrm{mmol})$ in dichloromethane $(100 \mathrm{~mL})$ at $0{ }^{\circ} \mathrm{C}$ under a nitrogen atmosphere. After $1 \mathrm{~h}$, the reaction mixture was added to saturated aqueous $\mathrm{NaHCO}_{3}(100 \mathrm{~mL})$ and extracted with EtOAc $(150 \mathrm{~mL})$. The organic phase was washed with water and evaporated to give $\mathbf{1 0}$ as a pale mauve solid (1.83 g, 94.3\%); mp 235 - $237{ }^{\circ} \mathrm{C}$; IR $\left(\mathrm{KBr}, \mathrm{cm}^{-1}\right)$ 3459, 3381, 1629; ${ }^{1} \mathrm{H}$ NMR (DMSO$\left.d_{6}\right) \delta 2.859(\mathrm{~s}, 3 \mathrm{H}), 3.092(\mathrm{~s}, 3 \mathrm{H}), 3.734(\mathrm{~s}, 2 \mathrm{H}), 6.074-6.096$ (dd, $1 \mathrm{H}, J=8.4$ and $0.8 \mathrm{~Hz}), 6.687-6.726(\mathrm{~m}, 1 \mathrm{H}), 6.920$ (s, 2H), 6.944-6.986 (m, 1H), 7.106-7.128 (dd, $1 \mathrm{H}, J=7.6$ and 1.6 $\mathrm{Hz}), 7.455(\mathrm{~s}, 1 \mathrm{H}) ;{ }^{13} \mathrm{C}$ NMR (DMSO- $\left.d_{6}\right) \delta 35.215,36.739$, 37.528, 113.292, 115.689, 118.684, 122.097, 127.133, 127.846, 129.999, 132.692, 144.454, 155.087, 170.536; ESI-MS: $\mathrm{M}+\mathrm{H}^{+}$ $(\mathrm{m} / \mathrm{z}) 339$.

4'-Hydroxydiclofenac (2). A solution of $\mathbf{1 0}$ (1.80 g, 5.31 $\mathrm{mmol})$ and $\mathrm{CuCl}(0.53 \mathrm{~g}, 5.31 \mathrm{mmol})$ in $\mathrm{EtOH}(50 \mathrm{~mL})$ was heated at reflux with $1 \mathrm{~N} \mathrm{NaOH}(30 \mathrm{~mL})$ for $24 \mathrm{~h}$ under a nitrogen atmosphere using a Schlenk tube. The dark brown solution was cooled, acidified to $\mathrm{pH} 2$ using $1 \mathrm{~N} \mathrm{HCl}$, and extracted with EtOAc $(150 \mathrm{~mL})$. The organic extract was washed with water and evaporated to give an orange-colored residue. After the residue was re-dissolved in $\mathrm{Et}_{2} \mathrm{O} / \mathrm{EtOAc}(\mathrm{v} / \mathrm{v}, 1 / 1)(15 \mathrm{~mL})$, the organic layer was extracted with saturated aqueous $\mathrm{NaHCO}_{3}$ solution $(50 \mathrm{~mL})$. The aqueous phase was acidified with $1 \mathrm{~N}$ $\mathrm{HCl}$ and then extracted with EtOAc $(120 \mathrm{~mL})$. The organic layer was concentrated in vacuo to give a light orange residue, which was purified by chromatography with a gradient eluent (from 25 to $70 \%$ EtOAc/Hexane) to afford $\mathbf{2}$ as a violet colored solid (1.49 g, 90.0\%); mp 177 - $178^{\circ} \mathrm{C}$ (lit. ${ }^{9} \mathrm{mp} 173$ - $175^{\circ} \mathrm{C}$ ); IR
$\left(\mathrm{KBr}, \mathrm{cm}^{-1}\right) 3459,3412,1692 ;{ }^{1} \mathrm{H}$ NMR (DMSO-d $)$ ) $\delta 3.645$ $(\mathrm{s}, 2 \mathrm{H}), 6.085-6.106(\mathrm{~d}, 1 \mathrm{H}, J=8.4 \mathrm{~Hz}), 6.698-6.734$ (t, $1 \mathrm{H}, J=$ $7.2 \mathrm{~Hz}), 6.859$ (s, 1H), 6.928 (s, 2H), 6.962-7.000 (t, 1H, $J=7.2$ $\mathrm{Hz}), 7.099-7.117(\mathrm{~d}, 1 \mathrm{H}, J=7.2 \mathrm{~Hz}), 10.202(\mathrm{~s}, 1 \mathrm{H}) ;{ }^{13} \mathrm{C} \mathrm{NMR}$ $\left(\mathrm{DMSO}-d_{6}\right) \delta 37.469,113.292,115.635,118.760,121.513$, 127.345, 127.808, 130.515, 312.813, 143.848, 155.118, 172.765; ESI-MS: M-H $(\mathrm{m} / \mathrm{z})$ 310, M-CO $-\mathrm{H}^{-}(\mathrm{m} / \mathrm{z}) 266$.

Acknowledgments. This research was supported by the BK21 program and Mid-career Researcher Program through NRF grant funded by the MEST (grant number 2008-0062072).

\section{References}

1. Tang, W. Current Drug Metabolism 2003, 4, 319.

2. Vail, R. B.; Homann, M. J.; Hanna, I.; Zaks, A. J. Ind. Microbiol. Biotechnol. 2005, 32, 67.

3. Masubuchi, Y.; Ose, A.; Horie, T. Drug Metabolism And Disposition 2001, 29, 1190.

4. Rainsford, K. D. Inflammopharmacology 1994, 2, 333.

5. Ponsoda, X.; Bort, R.; Jover, R.; Gómez-Lechón, M. J.; Castell, J. V. Toxic. In Vitro 1995, 4, 439.

6. Aithal, G. P.; Ramsay, K.; Daly, A. K.; Sonchit, L.; Leathart, J. B. S.; Alexander, G.; Kenna, J. G.; Caldwell, J.; Day, C. P. Hepatology 2004, $5,1430$.

7. Mehinto, A. C.; Hill, E. M.; Tyler, C. R. Environ. Sci. Technol. 2010, 44, 2176.

8. Waterhouse, I. J. Labelled Cpd. Radiopharm. 1999, 42, 1075.

9. Kenny, J. R.; Maggs, J. L.; Meng, X.; Sinnott, D.; Clarke, S. E.; Park, B. K.; Stachulski, A. V. J. Med. Chem. 2004, 47, 2816.

10. Hodmett, E. M.; Prakash, G.; Amirmoazzami, J. J. Med. Chem. 1978, 21,11

11. Oza, V. L.; Smith, C.; Raman, P.; Koepf, E. K.; Lashuel, H. A.; Petrassi, H. M.; Chiang, K. P.; Powers, E. T.; Sachettinni, J.; Kelly, J. W. J. Med. Chem. 2002, 45, 321.

12. Jolly, W. L. Synthetic Inorganic Chemistry; Prentice-Hall: 1960.

13. Kajimoto, T.; Takahashi, H.; Tsuji, J. Bull. Chem. Soc. Jpn. 1982, 55,367 . 